ORIGINAL ARTICLE

\title{
Correlation of Metabolic Syndrome with Genu Osteoarthritis in Type 2 Diabetes Mellitus Patients
}

\author{
Diaz Syafrie Abdillah ${ }^{1}$ (D), Ardyarini Dyah Savitri ${ }^{2 *}$, Effendi ${ }^{2}$ \\ ${ }^{1}$ Faculty of Medicine, Universitas Nahdlatul Ulama Surabaya - Jemursari Islamic Hospital Surabaya, Indonesia \\ ${ }^{2}$ Department of Internal Medicine, Faculty of Medicine, Universitas Nahdlatul Ulama Surabaya - Jemursari Islamic \\ Hospital Surabaya, Indonesia
}

\begin{abstract}
A B S T RA C T
Introduction: Genu Osteoarthritis is a joint disorder of the genu section due to a gradual decrease in cartilage bone cohesiveness. Metabolic syndrome by the International Diabetes Federation (IDF) was central obesity (abdominal circumference greater than $90 \mathrm{~cm}$ for Asian men and abdominal circumference greater than $80 \mathrm{~cm}$ for Asian women) plus two of the following four factors. This study aims to determine the relationship between metabolic syndrome and the incidence of osteoarthritis genu in type 2 DM patients at RSI Jemursari Surabaya.

Methods: This study uses an analytic observational approach with a cross-sectional design. This research data is secondary data from type 2 DM patients at Jemursari Islamic Hospital Surabaya from January 2018 to December 2018. The type 2 DM patients population and samples were obtained according to the inclusion and exclusion criteria. The sample size is 98 samples with a simple random sampling technique.

Results: In this study, the frequency of the metabolic syndrome in this study (31.6\%), age 55-65 years (38.7\%), male gender (51.6\%), and components of the metabolic syndrome include hypertension, type 2 diabetes, hypertriglyceridemia (83.9\%). On the frequency of Genu Osteoarthritis (28.6\%) with the age of 46-55 years (43\%), female gender (61\%). Osteoarthritis genu location distribution is mainly bilateral $(60.7 \%)$.

Conclusion: Based on the results of the Chi-Square Test statistical test using the SPSS statistical application, it shows a $p$ significance value of $0.080(>0.05)$.
\end{abstract}

Keywords: Metabolic syndrome, Genu Osteoarthritis, DM type 2

Correspondence: Ardyarini Dyah Savitri

E-mail: vitri.sppd@unusa.ac.id

Article history: $\bullet$ Received 10 July $2021 \bullet$ Received in revised form 17 November $2021 \bullet$ Accepted 1 December $2021 \bullet$ Available online 31 January 2022

\section{INTRODUCTION}

According to the American College of Rheumatology, OA is defined as a condition in which there are symptoms of disability in the articular cartilage integrity characterized by changes in the joint capsule. OA mainly affects weight-bearing joints such as the hips, knees, and spine, affecting the shoulders, finger joints, and ankles (Yovita \& Anggraini, 2014) (PAPDI, 2014).

Patients with OA with obesity more often complain of pain in the knee joint than $\mathrm{OA}$ in other joints, so that more OA genu sufferers are found, plus the degenerative age factor makes the supporting joints of the body, especially those in the genu region, experience cartilage damage (Yanuarty, 2014). OA is a degenerative joint disease associated with cartilage damage to the knee joint. Symptoms are often related to old age (Hendrati \& Anggraini 2014).

The most recent definition of metabolic syndrome by the International Diabetes Federation (IDF) in 2006 was central obesity (abdominal circumference greater than 90 $\mathrm{cm}$ for Asian men and abdominal circumference greater than $80 \mathrm{~cm}$ for Asian women) plus two of the following four factors: (IDF, 2006)

1. Triglycerides more than $150 \mathrm{mg} / \mathrm{dL}(1.7 \mathrm{mmol} / \mathrm{L})$ or being on medication for hypertriglyceridemia
2. HDL-C less than $40 \mathrm{mg} / \mathrm{dL}(1.03 \mathrm{mmol} / \mathrm{L})$ in men and less than $50 \mathrm{mg} / \mathrm{dL}(1.29 \mathrm{mmol} / \mathrm{L})$ in women or on medication for elevated HDL-C levels 3. Blood pressure: systolic more than 130 $\mathrm{mmHg}$ or diastolic more than $85 \mathrm{mmHg}$ or currently on hypertension treatment 4. Fasting blood sugar (GDP) more than $100 \mathrm{mg} / \mathrm{dL}$ $(5.6 \mathrm{mmol} / \mathrm{L})$, or previously diagnosed with type 2 diabetes.

One of the criteria of metabolic syndrome, namely hypertension, has a relationship with the occurrence of OA. According to Sheng Yao Liu in the journal Diabetology \& Metabolic Syndrome, the pathophysiology of hypertension that continues for a long time can reduce blood flow, especially in small subchondral vessels at the ends of long bones. This may lead to the occurrence of osteoarthritis (Liu et al., 2020). Meanwhile, in people who suffer from obesity, adipose tissue accumulation is very bad for the body.

A previous study provided the first evidence for a critical role for leptin in OA, thus providing an early meeting point for the journey to investigate adipokines as metabolic intermediaries between obesity and OA (Liu et al., 2020). Meanwhile, in people who suffer from obesity, adipose tissue accumulation is very bad for the body. A previous study provided the first evidence for a 
critical role for leptin in OA, thus providing an early meeting point for the journey to investigate adipokines as metabolic intermediaries between obesity and OA (Liu et al., 2020). Then in the condition of dyslipidemia, a condition where high levels of LDL, in addition to being the etiology of atherosclerosis, can cause an inflammatory reaction in cartilage and hyperglycemia conditions to exacerbate inflammatory responses (Courties et al., 2017).

Based on the description above, the researchers are interested in researching the relationship between metabolic syndrome and the incidence of OA genu in type 2 DM patients.

\section{METHODS}

This study used analytic observational research, and the research design was cross-sectional. The research data is secondary data from type two diabetes mellitus patients at Jemursari Islamic Hospital Surabaya from January 2018 to December 2018.

The sampling used in this study was carried out using probability sampling with the type of simple random sampling and based on inclusion and exclusion criteria. The chi-square test will determine the relationship between metabolic syndrome and osteoarthritis genu. Where the metabolic syndrome according to the definition of the International Diabetes Federation (IDF).

\section{RESULTS}

Table 1 Characteristics of Research Data

\begin{tabular}{|c|c|c|}
\hline \multirow{2}{*}{ Characteristics (Units) } & \multicolumn{2}{|c|}{ n:98 } \\
\hline & $\mathrm{n}(\%)$ & Average \pm \\
\hline \multicolumn{3}{|l|}{ Ages (years): } \\
\hline Metabolic Syndrome & & $60 \pm 5$ \\
\hline OA Genu & & $55 \pm 10$ \\
\hline \multicolumn{3}{|l|}{ Sex } \\
\hline \multicolumn{3}{|l|}{ Male } \\
\hline Metabolic Syndrome & $15(51.6)$ & \\
\hline OA Genu & $11(39)$ & \\
\hline \multicolumn{3}{|l|}{ Female } \\
\hline Metabolic Syndrome & $15(48.6)$ & \\
\hline OA Genu & $17(61)$ & \\
\hline $\begin{array}{l}\text { Frequency of Metabolic } \\
\text { Syndrome }\end{array}$ & $31(31.6)$ & \\
\hline \multicolumn{3}{|l|}{$\begin{array}{l}\text { Types of Components of } \\
\text { the Metabolic Syndrome }\end{array}$} \\
\hline $\begin{array}{l}\text { Hypertension, type } 2 \\
\text { DM, Hypertriglycerides }\end{array}$ & $26(83.9)$ & \\
\hline $\begin{array}{l}\text { Hypertention, type } 2 \\
\text { DM, HypoHDL }\end{array}$ & $5(16.1)$ & \\
\hline $\begin{array}{l}\text { Genu Osteoarthritis Fre- } \\
\text { quency }\end{array}$ & $28(28.6)$ & \\
\hline \multicolumn{3}{|l|}{$\begin{array}{l}\text { OA Genu Location Dis- } \\
\text { tribution }\end{array}$} \\
\hline Bilateral & $17(60.7)$ & \\
\hline Unilateral & $11(39.3)$ & \\
\hline
\end{tabular}

Table 2 Metabolic Syndrome Crosstabulation with Genu Osteoarthritis

\begin{tabular}{lccccccc}
\hline \multirow{2}{*}{$\begin{array}{l}\text { Metabolic } \\
\text { Syndrome }\end{array}$} & \multicolumn{4}{c}{ Genu Osteoarthritis } & \multicolumn{2}{c}{ Total } & \multirow{2}{*}{ p-value } \\
\cline { 2 - 6 } & \multicolumn{2}{c}{ Yes } & \multicolumn{2}{c}{ No } & & \\
\cline { 2 - 6 } & $\mathrm{N}$ & $\%$ & $\mathrm{~N}$ & $\%$ & $\mathrm{n}$ & $\%$ & \\
\hline Yes & 13 & 4 & 18 & 58 & 30 & 100 & \\
\hline No & 15 & 22.4 & 52 & 77.6 & 67 & 100 & 0.080 \\
\cline { 1 - 6 } Total & 28 & 28.6 & 70 & 71.4 & 98 & 1001 & \\
\hline
\end{tabular}

There are 98 subjects as the sample of this study analyzed. The following are the characteristics of the data of the subject of this study which are shown in table 1 . On condition metabolic syndrome, 31 subjects $(31.6 \%)$ experienced metabolic syndrome with the highest percentage being male, 16 subjects $(51.6 \%)$, and the average age is 56-65 years. There are two types of components of the metabolic syndrome, which are shown in table 2 , and the most common types are hypertension, type $2 \mathrm{DM}$, and hypertriglyceridemia, 26 subjects $(83.9 \%)$. Meanwhile, there were 28 subjects $(28.6 \%)$ with genu osteoarthritis, 17 subjects (61\%) with OA genu, and the average age was $55-65$ years. The most common occurrence in location distribution is Bilateral OA genu, 17 subjects (61\%). The relationship between metabolic syndrome and $\mathrm{OA}$ genu obtained a p-value of $0.080(>0.05)$, as shown in table 2 , which means there is no significant relationship between metabolic syndrome and osteoarthritis genu.

\section{DISCUSSION}

The frequency of occurrence of metabolic syndrome showed as much as $31.6 \%$. This is following previous research by Kamso et al. (2016), which showed that, in general, the prevalence of metabolic syndrome was high (21.6\%). Rini's study (2015) the majority of metabolic syndrome globally is $20-25 \%$. When viewed from the prevalence of the metabolic syndrome in the research area compared to the bulk of the metabolic syndrome in the world, most of the Jemursari Hospitals are experiencing an increase in the economy so that the incidence of obesity increases. WHO (World Health Organization) reports that nutritional and non-nutritional factors such as physical activity, alcohol, smoking, and stress can risk metabolic syndrome (Iqbal et al., 2020). The frequency of OA genu with type $2 \mathrm{DM}$ is as much as $28.6 \%$, and this is following previous research $(\mathrm{Li}$ et al. 2016). Regarding the relationship between OA genu and type $2 \mathrm{DM}$ itself, the prevalence was $24 \%$, a population analyzed by NHANES III, the majority of OA was $35 \%$ (Nguyen, 2014).

Terms of age, this condition is also a risk factor. As evidenced by an increase in the incidence of metabolic syndrome at the age above 55 years to 65 years, $35.5 \%$ - 38, $7 \%$. However, at the age of more than 65 years, there was a decrease $(23.9 \%)$.

The author's analysis, this happens because of the uneven distribution of age taken through simple random sampling, and the authors include the exclusion criteria, namely menopause, in this study. When viewed from previous studies, the older the age, the greater the occurrence of metabolic syndrome, at the age of 20-49, the positive metabolic syndrome was $(77.30 \%)$ and at the age of more than 50 years $(79.10 \%)$ (Mumusoglu \& Yildiz, 2019). While in OA, genu age is also one of the risk factors. The percentage obtained is $82 \%$ at $46-65$ years. This is following previous research by Yovita \& Anggraini (2014) regarding 
the prevalence of osteoarthritis of the genu mostly at more than 55 years $(62.5 \%)$. Another study by (Chen et al., 2020) also stated that the prevalence of OA genu increased at the age of more than 65 years suffering from genu osteoarthritis. Another source indicates that overall OA genu occurs at the age of over 50 years (Hasiibi, 2015; Nguyen, 2014).

In terms of the religion of Islam, the older a person gets, the more age he returns to being in a weak state after previously being in a vital state. This is already stated in QS. Ar-Ruum: 54 "Allah, it is He Who created you from a weak state, then He made (you) after the weak state became strong, then He made (you) after being strong-weak (back) and gray hair. He creates what He wills, and He is All-Knowing, All-Powerful." There are differences in results based on gender between metabolic syndrome and OA genu. In metabolic syndrome, men dominate with a percentage of $51.60 \%$. The factor that causes the distribution of lipid disease in men more than women is that men have low estrogen levels. In contrast, non-menopausal women have high estrogen levels because one of the functions of the hormone estrogen is to regulate fat metabolism and reduce the activity of Lipo Protein Lipase (LPL), a lipogenic enzyme that regulates lipid uptake (Kamso et al., 2016).

While in OA genu, women dominate with $61 \%$, this is following previous research by Yovita (2014), which found women were higher $(60.9 \%)$ than men $(39.1 \%)$, and in Hasiibi's study (2015) states that it is more in women $(57.1 \%)$ than men $(42.9 \%)$. According to the author's analysis, apart from the theoretical concept of OA genu, the number of patients with osteoarthritis genu in women cannot be separated from the sampling in this study, mostly found in the female sex over 50 years old. There are two types of components of the metabolic syndrome in the results of this study, i.e., type A, i.e., hypertension, type $2 \mathrm{DM}$, and hypertriglyceridemia and type B, namely Hypertension with type 2 DM and HypoHDL. The study's distribution of OA genu locations was mostly bilateral $(85.1 \%)$. According to Husnah and Wardhana's research in 2019, the condition of the number of bilateral OA genu due to abnormal loading in healthy knees in OA patients indicates that patients with unilateral OA genu can develop into bilateral OA genu to changes in on gait over time. Based on table 2, it can be informed that the results of the Chi-Square Test statistical test using SPSS statistics show a significance value of $0.080(>0.05)$, which means that there is no significant relationship between metabolic syndrome and osteoarthritis genu. This is because several factors make the results of this study unrelated and different from the effects of previous studies and theories.

In a study by Courties et al. (2017), who observed the relationship between the metabolic syndrome and osteoarthritis of the genu, the results showed that there was a relationship between the metabolic syndrome and osteoarthritis of the genu, with statistical results $59 \%$ of the metabolic syndrome being positive for OA genu and $23 \%$ only experiencing the metabolic syndrome [odds ratio (odds ratio). OR) $11.95 \%$ confidence interval (CI) 2.12-56.99]. In terms of the source of the previous theory, there is a relationship between metabolic syndrome and osteoarthritis of the genu because several components of the metabolic syndrome, namely hyperglycemia, dyslipidemia (low HDL levels and high triglyceride levels), hypertension, and central obesity, show that there is an independent association with OA genu which can damage or increase joint damage. There are inflammatory cells in common in the pathophysiology of OA genu with the metabolic syndrome (Courties et al.,
2017).

Several pathophysiological components of the metabolic syndrome, ranging from elevated triglyceride levels and low high-density lipoprotein/HDL cholesterol levels, can affect OA genu. Triacylglycerols or triglycerides are the main reserve fatty acid form and are esters of glycerol alcohol with fatty acids. Triglycerides are energy substances. Fat is stored in the body in the form of triglycerides. When cells need energy, lipase enzymes in fat cells will break down triglycerides into glycerol and fatty acids and release them into the blood vessels. High-density lipoprotein (HDL or -lipoprotein) helps remove fat deposits in blood vessels. The more HDL levels in the blood, the better the heart (Glyn-Jones et al., 2015; Sherwood, 2012). Low HDL cholesterol levels can increase the risk of heart attack and stroke. The total levels of fatty acids and arachidonic acid in chondrocytes of osteoarthritic cartilage were found to increase markedly with the severity of cartilage damage. Several studies have shown that specific fatty acids such as linoleic acid can modulate chondrocyte activation, mainly by reducing PGE2 and nitric oxide (NO) production, thereby inducing a protective effect, at least in vitro enhancing the inflammatory component of osteoarthritis (Grundy, 2018; Yovita \& Anggraini, 2014). The second component included in this study is hypertension. Hypertension is a pressure that helps blood flow to the blood vessels. High blood pressure is a condition when the blood pressure in the arteries is too high. If high blood pressure persists for an extended period, the blood vessels will thicken and become less flexible. This is called atherosclerosis, and it can affect the arteries that supplyblood to the heart(Rini, 2015). The effect of hypertension on small blood vessels in the long term will result in reduced blood flow in subchondral blood vessels, or is called subchondral ischemia. As well as obstruction by narrowing the vessel lumen, blood flow can also be reduced by venous occlusion and stasis or by the development of microemboli in the subchondral vessels. The two main subsequent effects of subchondral ischemia may lead to OA. One possibility is that subchondral ischemia reduces nutrient and gas exchange between articular cartilage and bone (Liu et al., 2020). The third component of this study is type 2 diabetes, a condition in which insulin resistance occurs, a need in which glucose uptake stimulated by insulin in various tissues such as liver, fat tissue, skeletal muscle is reduced (cannot use insulin efficiently). This causes the level of glucose in the blood to increase. High glucose levels for a long time can cause endothelial dysfunction and ultimately accelerate the atherosclerotic process (Valdes, 2020). The journal Diabetology \& Metabolic Syndrome by ShengYao Liu (2020) stated an independent correlation between genu osteoarthritis and hyperglycemia. In a body with high glucose concentrations, oxidative stress will occur and cause products of inflammatory factors (Liu et al., 2020).

Type 2 diabetes is a predictor of joint space reduction in men with OA genu. Hyperglycemia can cause cartilage protein glycation, especially showing a drastic decrease in type II collagen. In addition, several recent studies suggest that the role of AGEs is to increase the production of interleukin six and matrix metalloproteinase (MMP)-13 and the expression of cyclooxygenase two and reduce collagen II in human OA chondrocytes. That prolonged hyperglycemia is known to cause degradation of cartilage matrix proteins, especially in the genu region (Eymard et al., 2015; Li et al., 2016). 
Although there is no statistical relationship in this study, theoretically, from several sources, it has been stated that there is a relationship between the pathophysiology of metabolic syndrome and knee osteoarthritis. The factors that make this study not follow the initial hypothesis include a population of about 4000 subjects taken with a sample using the Slovin formula. A sample of 98 subjects was obtained not to reflect the population picture. This happens because in the calculation technique of sampling by researchers using $10 \%$ or with a CI of $90 \%$, by using $10 \%$, a sample that is not too large will be obtained so that it does not represent the population picture. And in this condition, there isn't one of the criteria for metabolic syndrome is central obesity in the medical record.

\section{CONCLUSION}

In this study, there was no significant relationship between metabolic syndrome and genu osteoarthritis in type $2 \mathrm{DM}$ patients at RSI Jemursari Surabaya with a significance value of $0.080(>0.05)$.

\section{ACKNOWLEDGEMENT}

The author thanks the parties involved in completing this study:

1. Ardyarini Dyah Savitri, dr., Sp.PD and Effendi, dr., Sp.PD ware examiner who provided advice and shared helpful knowledge in the preparation of this research.

2. Field of Research and Development in Jemursari Islamic Hospital Surabaya and his staff who helped and gave permission in this study.

3. Agus Aan Adriansyah S.KM., M.Kes was methodology and statistics supervisor.

\section{CONFLICT OF INTEREST}

The authors declare there is no conflict of interest.

\section{REFERENCES}

Chen Y, et al. 2020. Metabolic syndrome and semen quality in adult population. Journal of Diabetes 12(4):294-304.

Courties A, Jérémie S, Francis B. 2017. Metabolic syndromeassociated osteoarthritis. Current Opinion in Rheumatology 29(2):214-222.

Eymard F, et al. 2015. Diabetes is a risk factor for knee osteoarthritis progression. Osteoarthritis and Cartilage 23(6):851-859.

Glyn-Jones S, et al. 2015. Osteoarthritis. The Lancet 386(9991):376-387.

Grundy SM. 2018. Metabolic syndrome. In Dallas: Center for Human Nutrition and Department of Internal MedicineUT
Southwestern Medical Center, 71-107. Available at http:// link.springer.com/10.1007/978-3-319-44433-8_3.

Hasiibi W. 2015. Prevalensi dan distribusi osteoartritis lutut berdasarkan karakteristik sosio-demografi dan faktor risiko di wilayah kerja Puskesmas Susut I, Kecamatan Susut, Kabupaten Bangli pada tahun 2014. Intisari Sains Medis 4(1):32.

IDF. 2006. IDF Consensus Worldwide Definition of the Metabolic Syndrome. Brussels. Available at https://www. idf.org/e-library/consensus-statements/60-idfconsensusworldwide-definitionof-the-metabolic-syndrome.html Accessed 20 November 2021).

Iqbal SP, et al. 2020. Relationship of sociodemographic and lifestyle factors and diet habits with metabolic syndrome (MetS) among three ethnic groups of the malaysian population. PLOS ONE 15(3).

Kamso S, et al. 2016. Prevalensi dan determinan sindrom metabolik pada kelompok eksekutif di Jakarta dan sekitarnya. National Public Health Journal 6(2):85.

Li H, Daniel MG, Ruurd LJ, Xinzhan M. 2016. Metabolic syndrome and components exacerbate osteoarthritis symptoms of pain, depression and reduced knee function. Annals of translational medicine 4(7):133.

Liu S, et al. 2020. Bidirectional association between metabolic syndrome and osteoarthritis: a meta-analysis of observational studies. Diabetology \& Metabolic Syndrome 12(1):38.

Mumusoglu S, Bulent OY. 2019. Metabolic syndrome during menopause. Current Vascular Pharmacology 17(6): 595-603.

Nguyen TV. 2014. Osteoarthritis in Southeast Asia. International Journal of Clinical Rheumatology 9(5): 405408.

PAPDI. 2014. Buku ajar ilmu penyakit dalam, 6th ed. In: Setiati S, Alwi I, Sudoyo AW, Setiyohadi B(eds). Jakarta, Interna Publishing.

Rini S. 2015. Sindrom Metabolik. Jurnal Majority 4(4): 88-93.

Sherwood L. 2012. Fisiologi manusia dari sel ke sistem, 6th ed. Jakarta, EGC.

Valdes AM. 2020. Metabolic syndrome and osteoarthritis pain: common molecular mechanisms and potential therapeutic implications. Osteoarthritis and Cartilage 28(1): 7-9.

Yanuarty M. 2014. Hubungan antara faktor risiko osteoartritis lutut dengan nyeri, disabilitas, dan berat ringannya osteoartritis. Jurnal Media Medika Muda.

Yovita HL, Anggraini NE. 2014. Hubungan obesitas dan faktor-faktor pada individu dengan kejadian osteoarthritis genu 2. Surabaya, Universitas Airlangga. 